Volume 1 Issue 2, July-December 2020: pp.93-106.

Faculty of Law, Universitas Lampung, Bandar Lampung, Indonesia. http://jurnal.fh.unila.ac.id/index.php/ip

\title{
Perlindungan Hukum Terhadap Anak Sebagai Pekerja Seks Komersial Dalam Tindak Pidana Human Trafficking
}

\section{Legal Protection of Children as Commercial Sex Workers in Human Trafficking Crime}

\author{
Intan Syapriyani \\ intansyapriyani1996@yahoo.com
}

Fakultas Hukum Universitas Lampung

Submitted: Jul 14, 2020; Reviewed: Jul 30, 2020; Accepted: August 21, 2020

\section{Info Artikel \\ Kata Kunci: Perlindungan Hukum; Anak; Human Trafficiking. \\ Keywords: Legal Protection; Children; Human Trafficking.}

DOI:

https://doi.org/10.25041/ip.v1i2.2040

\begin{abstract}
Abstrak
Perlindungan anak adalah segala usaha yang dilakukan untuk menciptakan kondisi agar setiap anak dapat melaksanakan hak dan kewajibannya demi perkembangan dan pertumbuhan anak secara wajar, baik secara fisik, mental dan sosial. Kegiatan perlindungan anak membawa akibat hukum, baik dalam kaitannya dengan hukum tertulis maupun hukum tidak tertulis. Namun di Indonesia penegakan Hak Asasi Manusia nampaknya tidak begitu memperhatikan aspek perlindungan anak. Tingginya angka kejahatan perdagangan anak menunjukkan belum seriusnya upaya pemerintah terhadap pelaksanaan perlindungan anak. Metode penelitian yang digunakan adalah secara pendekatan yuridis normatif. Data yang digunakan dalam penulisan ini merupakan data yang diperoleh dari bahan-bahan pustaka. Hasil dari penelitian ini diketahui bahwa Bentuk perlindungan yang diberikan oleh Undang-undang Nomor 35 tahun 2014 tentang Perlindungan Anak di atur di dalam Pasal 68
\end{abstract}


yang menyebutkan bahwa Perlindungan khusus bagi anak korban penculikan, penjualan dan/atau perdagangan dilakukan melalui upaya pengawasan, perlindungan, pencegahan, perawatan dan rehabilitasi. Sedangkan Perlindungan terhadap anak sebagai korban perdagangan orang, berdasarkan Undang-undang. Nomor 21 Tahun 2007 tentang Pemberantasan Tindak Pidana Perdagangan Orang mengatur mengenai perlindungan saksi dan korban, tindak pidana dilaksanakan berdasarkan Undang-undang. Nomor 13 Tahun 2006 tentang Perlindungan Saksi dan Korban. Model perlindungan berdasarkan Undangundang Nomor 21 Tahun 2007 tentang PTPPO tidak membedakan antara anak dengan orang dewasa. Saksi korban dan pelapor dalam perkara anak mesti mendapatkan perlindungan dan bantuan hukum. Implementasi Undang Undang Perlindungan Anak (UUPA) di Indonesia dirasa masih sangat sulit diberlakukan secara sungguh-sungguh dan masih menjadi kendala. Penyebabnya tidak lain dari banyaknya yang turut menjadi konsumen atau pengguna jasa pekerja seks anak.

\section{Abstract}

Child protection is any effort made to create conditions so that every child can carry out their rights and obligations for the development and growth of children naturally, physically, mentally and socially. Child protection activities bring legal consequences, both in relation to written law and unwritten law. But in Indonesia the enforcement of human rights does not seem to pay much attention to aspects of child protection. The high crime rate of child trafficking shows that the government's efforts to protect child protection are not yet serious. The research method used is a normative juridical approach. The data used in this paper is data obtained from library materials. The results of this study note that the form of protection provided by Law No. 35 of 2014 concerning Child Protection is stipulated in Article 68 which states that special protection for child 
victims of abduction, sale and / or trafficking is carried out through surveillance, protection, prevention efforts, care and rehabilitation. While the protection of children as victims of trafficking in persons, based on the law. Number 21 of 2007 concerning Eradication of Trafficking in Persons Crimes regulates the protection of witnesses and victims, criminal acts carried out under the Law. Number 13 of 2006 concerning Protection of Witnesses and Victims. The protection model based on Law Number 21 Year 2007 regarding PTPPO does not differentiate between children and adults. Victim witnesses and reporters in child cases must receive protection and legal assistance. The implementation of the Child Protection Act (UUPA) in Indonesia is still very difficult to be taken seriously and is still an obstacle. The reason is none other than the number of people who have become consumers or users of child sex worker services.

\section{A. Pendahuluan}

Konvensi Hak Anak (KHA) yang sudah diratifikasi melalui Keputusan Presiden Nomor 36 Tahun 1990, menginstruksikan kaidah tersebut ke dalam hukum nasional, maksudnya pemerintah memiliki sebagai negara peserta (state party) mengikatkan diri dan sekaligus menggunakan konvensi tersebut sebagai sumber hukum nasional yang berkaitan dengan implementasi konvensi hak anak, mempunyai 2 konsekwensi hukum, yaitu mengakui hak-hak anak (legislation of children right), kewajiban negara untuk melaksanakan dan menjamin terlaksananya hak-hak anak (enforcement of children rights). ${ }^{1}$ Secara universal anak mempunyai hak asasi manusia yang dilindungi hukum, bahkan berlaku sejak dalam kandungan, karena itu anak juga berhak mendapat perlindungan hukum atas segala kegiatan yang mengarah pada pertumbuhan maupun perkembangan di masa mendatan. ${ }^{2}$

Anak merupakan generasi bangsa yang akan datang, kehidupan anak merupakan cermin kehidupan bangsa dan negara. Kehidupan anak yang diwarnai dengan keceriaan merupakan cermin suatu negara memberikan jaminan kepada anak untuk dapat hidup berkembang sesuai dengan dunia anak-anak itu sendiri. Banyak kejahatan yang terjadi terhadap anak, salah satunya adalah anak menjadi korban Human Trafficking. Anak-anak seringkali dijadikan objek eksploitasi ekonomi dan lain sebagainya, dikota-kota besar anak-anak dijadikan objek belas kasihan oleh orang tuanya dengan cara mendorong anak-anaknya supaya menjadi pengemis dan lain-lain. ${ }^{3}$ Tindak pidana perdagangan orang umumnya dilakukan dengan cara pelanggaran

\footnotetext{
${ }^{1}$ Eka Intan Putri, "Begal Anak; Pemenuhan Hak Dan Lembaga Pembinaan Khusus Anak Kelas II A Bandar Lampung," Cepalo 2, no. 2 (September 12, 2019): 45-84, https://doi.org/10.25041/cepalo.v2no2.1764. hlm 77.

2 Ardianto, "Perlindungan Hukum Terhadap Anak Sebagai Korban Dari Tindak Pidana Perdagangan Orang Di Kota Pekanbaru." Jurnal Ilmu Hukum, Vol. 4; No. 1, (accessed July 16, 2020): 1-31, https://jih.ejournal.unri.ac.id/index.php/JIH/article/view/1041/1034. hlm 2.

${ }^{3}$ Laurensius Arliman Simbolon, "Partisipasi Masyarakat Di Dalam Perlindungan Anak Yang Berkelanjutan Sebagai Bentuk Kesadaran Hukum," PADJADJARAN Jurnal Ilmu Hukum (Journal of Law) 3, no. 2 (October 20, 2016): 310-29, https://doi.org/10.22304/pjih.v3n2.a5. hlm 311.
} 
terhadap hak asasi manusia, yaitu berupa pelanggaran harkat dan martabat manusia yang berupa perlakuan kejam, dan bahkan perlakuan serupa perbudakan. ${ }^{4}$ Salah satu aspek perbudakan modern yang memprihatinkan adalah dijadikannya kehidupan manusia sebagai komoditi perdagangan, penempatan nilai moneter pada kehidupan seorang wanita, pria, atau anak-anak. ${ }^{5}$ Tindak pidana perdagangan orang juga merupakan salah satu bentuk perlakuan terburuk dari pelanggaran harkat dan martabat manusia. ${ }^{6}$

Masalah Perdagangan Orang (Human Trafficking) bukan lagi hal yang baru, tetapi sudah menjadi masalah nasional dan internasional yang berlarut-larut, hingga sampai saat ini belum dapat diatasi secara tepat, baik oleh pemerintah setiap Negara, maupun oleh organisasiorganisasi internasional yang berwenang dalam menangani masalah perdagangan orang tersebut. Akhir-akhir ini di Indonesia maupun di negara lain terjadi peningkatan pelanggaran Hak Asasi Manusia termasuk anak, dimana salah satunya Anak diperdagangkan sebagai Pelaku Seks Komersial. Human Traficking merupakan salah satu bentuk kejahatan yang sangat sulit untuk diberantas dan sebagai salah satu bentuk perbudakan modern dan pelanggaran terhadap hak asasi manusia. ${ }^{7}$ Human trafficking terjadi baik dalam tingkat nasional maupun internasional. Dengan berkembangnya teknologi informasi, komunikasi dan transformasi, maka modus kejahatan human trafficking pun semakin canggih. Human trafficking merupakan kejahatan yang luar hbiasa (extra ordinary), terorganisir (organized), dan lintas negara (transnational), sehingga dapat dikategorikan sebagai transnational organized crime (TOC). ${ }^{8}$

Anak adalah bagian dari generasi muda sebagai salah satu sumber daya manusia yang merupakan potensi dan penerus citacita perjuangan bangsa, yang memiliki peranan strategis dan mempunyai ciri dan sifat yang khusus, memerlukan pembinaan dan perlindungan dalam rangka menjamin pertumbuhan dan perkembangan fisik, mental, dan sosial secara utuh, serasi, selaras, dan seimbang. ${ }^{9}$ Perlindungan terhadap anak merupakan tanggung jawab orang tua, keluarga, maupun masyarakat sekitarnya. Perlindungan yang diberikan pada anak merupakan untuk menjamin dan melindungi anak dan hak-hak anak untuk dapat hidup, tumbuh, berkembang dan juga dapat bersosialisasi di lingkungan sekitarnya. Sebagian besar korban perdagangan manusia adalah perempuan. Mereka dijual untuk menjadi pekerja di sektor berbahaya, seperti seks komersial. ${ }^{10}$ Untuk mengatasi hal tersebut, upaya penanggulangan kejahatan perdagangan orang melalui hukum pidana formal (sarana penal) mengarah pada penegakan hukum secara represif. ${ }^{11}$

\footnotetext{
${ }^{4}$ Henny Nuraeny, "Penyuluhan Hukum Mengenai Undang-Undang Nomor 21 Tahun 2007 Tentang Pemberantasan Tindak Pidana Perdagangan Orang Bagi Guru Bimbingan Konseling Dan Siswa/Siswi Smk/Sma/Ma Se-Kabupaten Cianjur," Journal Of Empowerment, vol. 1, No. 1, (July 1, 2017): 25-38, https://jurnal.unsur.ac.id/index.php/JE. hlm 29.

5 Agung Sulistiyo, "Perlindungan Korban Kekerasan Kejahatan Perdagangan Manusia Dalam Sistem Hukum Pidana Indonesia," Pandecta : Jurnal Penelitian Ilmu Hukum (Research Law Journal), vol. 7, No. 2 (2012): 156-170, http://journal.unnes.ac.id/nju/index.php/pandecta. hlm 158.

${ }^{6}$ tri Wahyu Widiastuti, "Upaya Pencegahan Tindak Pidana Perdagangan Orang (Trafficking)," Wacana Hukum, vol. 9, No. 1 (September 22, 2012): 107-120, http://www.ejurnal.unisri.ac.id/index.php/Wacana/article/view/308. hlm 107.

${ }_{7}$ Gultom Maidin, Perlindungan Hukum Terhadap Anak Dan Perempuan, Refika Aditama, Bandung, 2013, hlm 41.

${ }^{8}$ Ikhlasiah Dalimoenthe, “Jurnal Pendidikan Ilmu-Ilmu Sosial Pemetaan Jaringan Sosial Dan Motif Korban Human Trafficking Pada Perempuan Pekerja Seks Komersial," JUPIIS: JURNAL PENDIDIKAN ILMU-ILMU SOSIAL, vol. 10, No. 1(June 29, 2018): 91-103, https://doi.org/10.24114/JUPIIS.V10I1.8430.G9061. hlm 92.

${ }^{99}$ Ayu Amalia Kusuma, "Efektivitas Undang-Undang Perlindungan Anak Dalam Hubungan Dengan Perlindungan Hukum Terhadap Anak Korban Perdagangan Orang Di Indonesia,” LEX ET SOCIETATIS, vol. 3, (February 13, 2015): 64-71, http://news.okezone.com/read/2014/. hlm 64.

10 Asiyah Jamilah and Nyoman Serikat Putra Jaya, "Penanggulangan Kejahatan Perdagangan Orang Dari Perspektif Politik Kriminal," JUSTITIA JURNAL HUKUM. Vol.4, no. 1 (April 15, 2020): 1-18, https://m.liputan6.com/regional/read. hlm 1.

${ }^{11}$ Hasyim Azizurrahman, " Pembaharuan Kebijakan Pidana Kejahatan Perdagangan Orang (Studi Di Wilayah Perbatasan Kalimantan Barat-Sarawak)." Yustisia Jurnal Hukum, Vol. 3, No. 2 (accessed July 16, 2020): 88-99, https://jurnal.uns.ac.id/yustisia/article/view/11100/9932. hlm 88 .
} 
Menurut Undang-Undang RI Nomor 21 tahun 2007 tentang pemberantasan tindak pidana perdagangan orang (TPPO) adalah tindakan perekrutan, pengangkutan, penampungan, pengiriman, pemindahan atau penerimaan seseorang dengan ancaman kekerasan, penggunaan kekerasan, penculikan, penyekapan. ${ }^{12}$ Kemudian, pemalsuan, penipuan dan penyalahgunaan kekuasaan atau posisi rentan, penjeratan uang atau memberikan bayaran atau manfaat, sehingga memperoleh persetujuan dari orang yang memegang kendali atas orang lain tersebut, baik yang dilakukan di dalam negara maupun antar negara, untuk tujuan eksploitasi atau mengakibatkan orang terekploitasi. Pengertian eksploitasi adalah tindakan dengan atau tanpa persetujuan korban yang meliputi tetapi tidak terbatas pada pelacuran, kerja atau pelayanan paksa, perbudakan atau praktik serupa perbudakan, penindakan, pemerasan, pemanfaatan fisik, seksual, organ reproduksi atau secara melawan hukum memindahkan Atau mentransplantasi organ dan atau jaringan tubuh atau memanfaatkan tenaga atau kemampuan seseorang oleh pihak lain untuk mendapatkan keuntungan baik materiil maupun immaterial.

Perlindungan Anak diatur didalam Undang-undang khusus yakni Undang-Undang Nomor 17 Tahun 2016 jo Undang-Undang Nomor 35 Tahun 2014 jo Undang-undang Nomor 23 tahun 2002 tentang Perlindungan Anak. Dalam Pasal 13 Undang-undang Nomor 23 tahun 2002 menyatakan bahwa setiap anak selama dalam pengasuhan orang tua, wali, atau pihak lain manapun yang bertanggung jawab atas pengasuhan, berhak mendapat perlindungan dari perlakuan diskriminasi; eksploitasi, baik ekonomi maupun seksual; penelantaran; kekejaman, kekerasan, dan penganiayaan; ketidakadilan; dan perlakuan salah lainnya. Pengaturan pencegahan perdagangan sangat erat kaitannya dengan perkembangan hak asasi manusia di Indonesia., dimana keduanya tidak dapat dipisahkan dari konsep hukum alam. ${ }^{13}$

Banyak regulasi yang mengatur mengenai tindak pidana perdagangan orang (human trafficking) untuk anak, salah satunya Pasal 76F Undang-undang Nomor 35 Tahun 2014 tentang Perubahan atas Undang-undang Nomor 23 Tahun 2002 tentang Perlindungan Anak menyebutkan: "Setiap orang dilarang menempatkan, membiarkan, melakukan, menyuruh melakukan, atau turut serta melakukan penculikan, penjualan, dan/atau perdagangan Anak."

Perlindungan anak adalah segala usaha yang dilakukan untuk menciptakan kondisi agar setiap anak dapat melaksanakan hak dan kewajibannya demi perkembangan dan pertumbuhan anak secara wajar baik secara fisik, mental dan sosial. Kegiatan perlindungan anak membawa akibat hukum, baik dalam kaitannya dengan hukum tertulis maupun hukum tidak tertulis. Hal ini sejalan dengan amanat Pasal 28B ayat (2) Undang-Undang Dasar Negara Republik Indonesia Tahun 1945. Perlindungan terhadap anak yang menjadi korban perdagangan orang berdasarkan amanat Undang-undang Republik Indonesia Nomor 35 Tahun 2014 tentang Perubahan atas Undang-Undang Nomor 23 Tahun 2002 tentang Perlindungan Anak disebutkan bahwa anak korban perdagangan orang mendapatkan perlindungan khusus yang wajib diberikan oleh Pemerintah, Pemerintah Daerah, dan Lembaga Negara lainnya (Pasal 59).

Permasalahan terkait HAM di Indonesia adalah tindak pidana perdagangan orang (human trafficking). ${ }^{14}$ Maraknya kasus perdagangan anak belum optimalnya upaya perlindungan anak dilakukan. Indonesia merupakan negara sumber, transit dan tujuan dari perdagangan orang terhadap perempuan dan anak, terutama untuk tujuan prostitusi dan ekpolitasi terhadap anak.

\footnotetext{
12 Okky RI Chahyo Nugroho, “Tanggung Jawab Negara Dalam Penanganan Tindak Pidana Perdagangan Orang (State's Responsibility in Mitigation of Human Trafficking Crime)," Jurnal Penelitian Hukum De Jure 18, Vol. 18, No. 4 (December 10, 2018): 16-27, https://doi.org/10.30641/dejure.2018.V18.543-560. hlm 544.

${ }^{13}$ Herlyanty And Yuliana Angraeny Bawole, "Implementasi Hukum Hak Asasi Manusia Dalam Pengaturan Pencegahan Tindak Pidana Perdagangan Orang Di Indonesia," LEX CRIMEN, vol. II, August 16, 2013): 97-111, https://ejournal.unsrat.ac.id/index.php/lexcrimen/article/view/2429. hlm 97.

${ }_{14}$ Muh Abdul Qudus, "Pertanggungjawaban Korporasi Terhadap Tindak Pidana Human Trafficking Di Indonesia," Jurnal

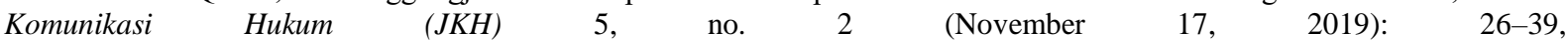
https://ejournal.undiksha.ac.id/index.php/jkh/article/view/18237. hlm 27. 
Fenomena perdagangan orang dewasa ini semakin beragam bentuk dan modusnya. Banyak pelacuran baik di area lokalisasi maupun ditempat-tempat pelacuran terselubung seperti di kafe, panti pijat, salon kecantikan plus-plus, hotel dan lain-lain mulai menjamur, baik di kota besar maupun di pedesaan. ${ }^{15}$ Kejahatan perdagangan orang adalah satu objek kejahatan yang semakin perkembang di Indonesia. Materi pengaturan pasal mengenai hal tersebut sudah diatur pada pasal 297 KUHP, namun sampai sejauh ini masih belum dirasakan kemanfaatannya. ${ }^{16}$ Upaya Perlindungan terhadap anak sebagai pekerja seks komersial merupakan hal yang kompleks karena beirisan dengan berbagai aspek kehidupan, maka diperlukan kesadaran dan peran serta seluruh masyarakat, penyelenggara negara dan aparat penegak hukum.

Masalah human trafficking dan eksploitasi anak hanya berfokus pada masalah yang sudah terjadi dan penyelesaian terhadap penanganan kasus. Sementara upaya pencegahan dan pemenuhan terhadap hak anak kurang menjadi perhatian. Peran serta masyarakat sangat di butuhkan baik secara kelembagaan maupun perserorangan yang dapat di mulai dari orangtua, guru, tokoh agama, tokoh masyarakat, pejabat pemerintah, harus bahu membahu menyadarkan para pihak yang berpotensi terjadinya tindak pidanaperdagangan orang. Pentingnya tugas Pemerintah Pusat dan Daerah untuk mensejahterakan warganya, untuk bisa memperdayakan masyarakat dan menyediakan pekerjaan yang layak dengan penghasilan yang mencukupi dan Sosialisasi tentang trafficking harus di berikan secara intensif khususnya bagi masyarakat yang berpendidikan rendah dan masyarakat yang bertaraf ekonomi rendah untuk mengingatkan agar tidak mudah menerima bujuk rayu dan iming-iming kehidupan mudah mewah tanpa pekerjaan yang jelas karena seungguhnya hal tersebut akan menjerumuskan. ${ }^{17}$

Adapun salah satu kasus human trafficking yang terjadi di lampung. Dimana Polres Lampung Timur berhasil membongkar praktik prostitusi pelajar. Praktik prostitusi pelajar itu didalangi ibu dan anak di Raman Utara, Lampung Timur, Provinsi Lampung. Tersangka PI (36) dan BA (21) mengaku telah menjalankan perdagangan anak di bawah umur selama kurang lebih tiga bulan. Dengan keuntungan 30 persen dari tarif yang disepakati. Keduanya telah menjual kesucian Senja (16), Jingga (16), dan Rona (15), bukan nama sebenarnya, kepada pria-pria hidung belang dengan tarif bervariasi, Rp 500 ribu hingga Rp 900 ribu. kedua tersangka (muncikari) diduga melakukan perdagangan dan mempekerjakan tiga wanita di bawah umur yang masih berstatus pelajar, untuk dijadikan Pekerja Seks Komersial (PSK) dengan imbalan uang. Profesi yang dijalani para tersangka sudah berlangsung sejak Desember 2018.

Adapun modus yang digunakan dengan cara menawarkan kepada pria-pria melalui jalur komunikasi telepon. Setelah sepakat, muncikari akan memberikan nomor telepon ABG kepada calon klien mesumnya. Ibu dan anak tersebut akan dijerat dengan Undang-Undang Nomor 21 tahun 2007 terkait Pemberantasan Tindak Pidana Perdagangan Orang dan Undang-Undang Nomor 35 Tahun 2014 (UU No. 35 Tahun 2014) tentang Perlindungan Anak, dengan ancaman hukuman 15 tahun penjara. ${ }^{18}$

Perdagangan anak merupakan masalah serius yang harus ditangani secara sungguhsungguh. Pasalnya, persoalan perdagangan anak di Indonesia sedang mendapat banyak sorotan. Bahkan Indonesia dinyatakan menempati urutan terburuk di dunia bersama dengan beberapa negara lain di Asia dalam hal perdagangan anak. Bahkan beberapa lembaga donor telah

\footnotetext{
${ }^{15} \mathrm{https}$ //endangshastuti.wordpress.com/perdagangan-manusia/ Diakses pada 10 Februari 2019 pukul 19:40 WIB.

${ }^{16}$ Alfan Alfian, "Upaya Perlindungan Hukum Terhadap Korban Tindak Pidana Perdagangan Orang Legal Protection Against Crime Victims of Human Trading," Fiat Justisia Jurnal Ilmu Hukum, Vol. 9, No. 3 (2015): 331-339, https://jurnal.fh.unila.ac.id/index.php/fiat/article/view/603. hlm 332.

${ }^{17}$ Irwanto, Perdagangan Anak di Indonesia, Suatu diskripsi Awal, Kantor Peburuhan Internasional, Jakarta, 2001, hlm. 71.

${ }^{18} \mathrm{http}$ ://jakarta.tribunnews.com/2019/01/12/prostitusi-pelajar-di-lampung-terbongkar-ibu-anak-jadi-muncikaribeginimodusnya?page=all\#gref Diakses pada 10 Februari 2019 pukul 19:40 WIB.
} 
memberi warning dengan menyatakan akan menghentikan bantuannya ke Indonesia jika tidak dapat segera memperbaiki keadaan tersebut, hal tersebut kemudian direspon oleh pemerintah dengan merumuskan UU No. 35 Tahun 2014 tentang Pelindungan Anak yang sebelumnya diatur dalam Undang-Undang Nomor 23 Tahun 2002 tentang Perlindungan Anak.

Undang-Undang Nomor 35 Tahun 2014 tentang Perlindungan Anak adalah sebuah undang-undang yang dirumuskan oleh pemerintah untuk menjamin hak anak yang mengacu pada prinsip-prinsip yang tercantum dalam Konvensi Hak Anak. Undang-undang ini mengartikan anak sebagai seseorang yang berusia di bawah 18 tahun dan melarang eksploitasi ekonomi atau seksual serta kekerasan dan pelecehan terhadap anak. Anak mempunyai kedudukan yang sangat strategis dalam bangsa, negara, masyarakat maupun keluarga. Anak merupakan tumpuan harapan masa depan bagi bangsa, negara, masyarakat maupun keluarga. Oleh karena itu kondisi anak perlu diperlakukan secara khusus agar dapat tumbuh dan berkembang secara wajar baik fisik, mental maupun rohaninya. Karenanya, dibutuhkan perlindungan khusus untuk menyelamatkan mereka.

Ketentuan Perdagangan Orang terdapat Undang-undang khusus yang mengaturnya, yaitu Undang-undang RI Nomor 21 Tahun 2007 Tentang Pemberantasan Tindak Pidana Perdagangan Orang (PTPPO), undang-undang khusus ini mengantisipasi dan menjerat semua jenis tindakan dalam proses, cara, atau semua bentuk eksploitasi yang mungkin terjadi dalam praktik perdagangan orang, baik yang dilakukan antarwilayah dalam negeri maupun secara antarnegara, dan baik oleh pelaku perorangan maupun korporasi. Perlindungan anak sebenarnya bagian yang terintegral dengan penegakan hak asasi manusia. Namun di Indonesia penegakan HAM nampaknya tidak begitu memperhatikan aspek perlindungan anak. Tingginya angka kejahatan perdagangan anak menunjukkan belum seriusnya upaya pemerintah terhadap pelaksanaan perlindungan anak. Hal tersebut sama artinya negara juga belum serius dalam menegakkan hak asasi manusia. ${ }^{19}$

Berdasarkan uraian diatas maka permasalahan dalam penulisan ini adalah menganalisa bagaimanakah perlindungan hukum terhadap Anak sebagai Pelaku Seks Komersial dalam Tindak Pidana Human Traficking dan bagaimana perlindungan anak sebagai pekerja seks komersial dalam perspektif hukum progresif. Pendekatan yang dilakukan dalam penulisan ini adalah secara pendekatan yuridis normatif. Data yang digunakan dalam penulisan ini merupakan data yang diperoleh dari bahan-bahan pustaka.

\section{B. Pembahasan}

\section{Perlindungan Hukum terhadap Anak sebagai Pelaku Seks Komersial dalam Tindak Pidana Human Trafficking}

Secara yuridis adanya delik tentang Perdagangan Orang kedalam Undang-Undang sangat diperlukan dengan mutlak untuk memakasa seseorang maupun masyarakat untuk mematuhi dan memberikan hukum yang mutlak dalam untuk siapapun yang melakukan setiap kejahatan tersebut. ${ }^{20}$ Perlindungan terhadap anak yang menjadi korban tindak pidana perdagangan orang tidak terlepas dari materi Hak Asasi Manusia yang diatur baik dalam peraturan perundangundangan maupun Konstitusi Negara Republik Indonesia. TAP MPR Nomor XVII/MPR/1998 tentang Hak Asasi Manusia (HAM) antara lain menyatakan bahwa pemahaman HAM bagi bangsa Indonesia adalah sebagai berikut:

\footnotetext{
${ }^{19}$ Muhtaj El Majda, Dimensi-dimensi HAM: MenguraI Hak Ekonomi, Sosial, dan Budaya, Rajawali Pers, Jakarta, 2008, hlm. 118 .

${ }^{20}$ Sitania, "Akomodasi Pemberantasan Tindak Pidana Perdagangan Orang Dalam Aspek Hukum Internasional Dan Nasional." Jurnal Pembangunan Hukum Indonesia. Vol. 2 No. 1 (accessed July 16, 2020): 38-53, https://ejournal2.undip.ac.id/index.php/jphi/article/view/7209/3695. hlm 41.
} 
"Hak asasi merupakan hak dasar seluruh umat manusia tanpa ada perbedaan. Mengingat hak dasar merupakan anugerah dari Tuhan Yang Maha Esa, maka pengertian Hak Asasi Manusia adalah hak sebagai anugerah Tuhan Yang Maha Esa yang melekat pada diri manusia, bersifat kodrati, universal dan abadi, berkaitan dengan harkat dan martabat manusia."

Jaminan terhadap perlindungan atas anak yang menjadi korban perdagangan orang (child trafficking) secara umum telah diamanatkan di dalam UUD Negara Republik Indonesia tahun 1945 Pasal 28 b ayat (2) yaitu "Hak anak untuk kelangsungan hidup, tumbuh, dan berkembang serta hak atas perlindungan dari kekerasan dan diskriminasi". ${ }^{21}$ Selain di dalam UUD Negara Republik Indonesia tahun 1945, Undang-undang Nomor 35 tahun 2014 tentang Perubahan atas Undang-Undang Nomor 23 Tahun 2002 tentang Perlindungan anak pada Pasal 59 menegaskan bahwa Pemerintah, Pemerintah Daerah dan lembaga negara lainnya berkewajiban dan bertanggungjawab untuk memberikan perlindungan khusus kepada anak yang dieksploitasi secara ekonomi dan/atau seksual, anak korban penculikan, penjualan dan/atau perdagangan.

Adapun bentuk perlindungan yang diberikan oleh Undang-undang Nomor 35 tahun 2014 tentang Perubahan atas Undang-Undang Nomor 23 tahun 2002 tentang Perlindungan Anak di atur di dalam Pasal 68 yang menyebutkan

"Perlindungan khusus bagi anak korban penculikan, penjualan dan/atau perdagangan dilakukan melalui upaya pengawasan, perlindungan, pencegahan, perawatan dan rehabilitasi."

Menurut Muladi dan Barda Nawawi Arief terdapat dua model perlindungan, yaitu: model hak-hak prosedural (the procedural right model) dan model pelayanan (the service model). Model hak-hak prosedural (the procedural right model), menekankan korban berperan aktif di dalam proses peradilan pidana. Model pelayanan (the service model) menekankan pada pemberian ganti kerugian dalam bentuk kompensasi, restitusi, dan upaya pengembalian kondisi korban yang mengalami trauma, rasa takut, dan tertekan akibat kejahatan sehingga diperlukan standar baku bagi pembinaan korban yang dapat digunakan oleh polisi. Korban akan merasa dijamin kembali kepentingannya dalam suasana tertib sosial yang adil. Model ini dapat menghemat biaya sebab adanya pedoman bantuan yang baku, serta mempertimbangkan kerugian-kerugian yang dialami korban. Model perlindungan terhadap anak korban tindak pidana perdagangan lebih sesuai dengan model pelayanan, yang dilakukan dengan pemberian ganti kerugian dalam bentuk kompensasi, restitusi, dan upaya pengembalian kondisi korban yang mengalami trauma, rasa takut, dan tertekan akibat kejahatan. Pemulihan kondisi anak sebagai korban akan lebih sulit dilakukan dan memakan waktu yang lama. ${ }^{22}$

Undang-undang Nomor 21 Tahun 2007 tentang PTPPO dilengkapi dengan PP. No. 9 Tahun 2008 tentang Tata Cara dan Mekanisme Pelayanan Terpadu Bagi Saksi dan/atau Korban Tindak Pidana perdagangan orang, yang di dalam Pasal 4 disebutkan bahwa dalam hal saksi dan/atau korban adalah anak, maka pelayanan diberikan secara khusus sesuai dengan kepentingan terbaik bagi anak. Selanjutnya di dalam penjelasannya diuraikan bahwa ketentuan ini dimaksudkan agar standar pelayanan minimal dan standar operasional prosedur pemulangan dan reintegrasi sosial terhadap anak sebagai saksi dan/atau korban ditentukan sesuai dengan prinsip konvensi hak anak, antara lain prinsip nondiskriminasi dan kepentingan terbaik bagi anak. $^{23}$

Perlindungan terhadap anak sebagai korban perdagangan orang, berdasarkan UU. No. 21 Tahun 2007 tentang PTPPO, Bab V, Pasal 43 menyebutkan perlindungan saksi dan korban tindak pidana dilaksanakan berdasarkan Undang-undang Nomor 13 Tahun 2006 tentang

\footnotetext{
${ }^{21}$ Moh. Hatta, Tindak Pidana Perdagangan Orang Dalam Teori Dan Praktek, Liberty Yogyakarta, Yogyakarta, 2012, hlm 10 .

${ }^{22}$ Muladi dan Barda Nawai Arif, Teori-Teori dan Kebijakan Pidana, Alumni, Bandung, 2010, hlm. 85.

${ }^{23}$ Muchamad Iksan, Hukum Perlindungan Saksi dalam Sistem Peradilan Pidana Indonesia, Muhammadiyah University Press, Surakarta, 2012, hlm. 201.
} 
Perlindungan Saksi dan Korban. Model perlindungan berdasarkan Undang-undang. Nomor 21 Tahun 2007 tentang PTPPO tidak membedakan antara anak dengan orang dewasa, Pasal 44 menjelaskan bahwa korban diberikan hak untuk kerahasiaan identitas korban dan saksi, serta keluarganya sampai derajat kedua. Pasal 47 memberikan tugas kepada Kepolisian Negara Republik Indonesia untuk memberikan perlindungan, baik sebelum, selama, maupun sesudah proses pemeriksaan perkara.

Anak sebagai korban perdagangan orang merupakan perampasan terhadap hak-hak, seperti: kebebasan bergerak, kebebasan berkumpul dan kebebasan memiliki serta kebebasan bersenang-senang atau bermain. Kehidupan anak di jalan sangat mempengaruhi partumbuhan fisik, sosial, emosional dan kesehatan. Khusus untuk anak terdapat beberapa pengalaman terhadap tumbuh dengan resiko yang tinggi, termasuk: (a) tidak dapat dilindunginya dari eksploitasi seksual, dan obat terlarang; (b) Kurang gizi, depresi dan kurang percaya diri; dan (c) Tidak mendapatkan pendidikan yang baik da kehidupan yang layak serta perlindungan terhadap dirinya.

Upaya perlindungan hukum terhadap anak yang menjadi korban tindak pidana perdagangan orang tidak hanya ditujukan terhadap anak namun juga ditujukan sebagai upaya pencegahan agar tidak terjadi tindak pidana perdagangan orang yang menjadikan anak sebagai korbannya. Undang-undang Nomor 35 tahun 2014 tentang Perubahan atas Undang-undang Nomor 23 tahun 2002 tentang Perlindungan Anak tidak menyebutkan secara spesifik bagaimana uraian detail perlindungan atas anak yang menjadi korban penculikan, perdagangan orang tersebut. Hanya di dalam Pasal 78 disebutkan bahwa siapa saja yang mengetahui dan sengaja membiarkan anak-anak tereksploitasi secara ekonomi dan/atau seksual, anak yang diperdagangkan akan dikenakan pidana.

Pasal 71 D disebutkan bahwa anak yang tereksploitasi secara ekonomi dan/atau seksual, anak yang diperdagangkan berhak mengajukan ke pengadilan berupa hak atas restitusi yang menjadi tanggung jawab pelaku kejahatan. Pasal 71 D ini berkaitan dengan hak yang didapat oleh anak sebagai korban setelah berlangsungnya proses persidangan.

Undang-undang Nomor 21 Tahun 2007 tentang Pemberantasan Tindak Pidana Perdagangan Orang, hanya memfokuskan pada pencegahan dan penanganan tindak pidana perdagangan orang. Untuk anak sebagai korban tindak pidana perdagangan orang, undangundang ini hanya mengatur sebatas apa yang diatur di dalam 9 buah Pasal yaitu Pasal 1 angka 5, Pasal 5, Pasal 6, Pasal 17, Pasal 38, Pasal 39 dan Pasal 40.

Upaya hukum perlindungan terhadap anak yang menjadi korban tindak pidana perdagangan orang baik di dalam Undang-undang Nomor 21 Tahun 2007 tentang Pemberantasan Tindak Pidana Perdagangan Orang dan Undang-undang Nomor 35 Tahun 2014 tentang Perubahan atas Undang-undang Nomor 23 Tahun 2002 tentang Perlindungan Anak dibagi atas 3 tahap yaitu perlindungan pada saat terjadinya tindak pidana, tahap persidangan pelaku tindak pidana dan tahap setelah putusan pengadilan. Adapun uraian 3 tahap tersebut yaitu:

1. Tahap perlindungan pada saat terjadinya tindak pidana perdagangan orang meliputi ancaman pemidanaan bagi siapa saja yang mengetahui dan sengaja membiarkan anak-anak yang tereksploitasi secara ekonomi dan/atau seksual, anak yang diperdagangkan (pasal 78 UU RI No. 35 tahun 2014)

2. Tahap perlindungan pada saat persidangan pelaku tindak pidana perdagangan orang meliputi: (UU RI No. 21 Tahun 2007)

a. Penyidikan, penuntutan, dan pemeriksaan di sidang pengadilan terhadap saksi dan/atau korban anak dilakukan dengan memperhatikan kepentingan yang terbaik bagi anak dengan tidak memakai toga atau pakaian dinas. 
b. Sidang tindak pidana perdagangan orang untuk memeriksa saksi dan/atau korban anak dilakukan dalam sidang tertutup.

c. Pemeriksaan saksi dan/atau korban anak wajib didampingi orang tua, wali, orang tua asuh, advokat, atau pendamping lainnya.

d. Pemeriksaan terhadap saksi dan/atau korban anak sebagaimana dimaksud pada ayat (1) dilaksanakan tanpa kehadiran terdakwa.

e. Pemeriksaan terhadap saksi dan/atau korban anak, atas persetujuan hakim, dapat dilakukan di luar sidang pengadilan dengan perekaman yang dilakukan di hadapan pejabat yang berwenang.

3. Tahap setelah persidangan yaitu pemberian hak untuk mengajukan ke pengadilan berupa hak restitusi yang menjadi tanggung jawab pelaku kejahatan (Pasal 71 D UU No. 35 Tahun 2014 Jo UU No 23 Tahun 2002 dan Pasal 48 sampai dengan Pasal 50 Undang-undang Nomor 21 Tahun 2007). ${ }^{24}$

Dari ketiga tahapan ini, upaya hukum perlindungan terhadap anak sebagai korban tindak pidana perdagangan orang pasca keluarnya putusan pengadilan terhadap pelaku hanya berbatas pada pemberian hak restitusi yang terlebih dahulu harus diajukan oleh korban dan/atau ahli warisnya. Ganti kerugian atau restitusi ini menurut hukum yang berlaku dapat dituntut melalui gugatan perdata maupun melalui proses pengadilan pidana. Dalam proses peradilan pidana dilakukan dengan cara mengajukan penggabungan perkara gugatan ganti kerugian/restitusi yang berdasarkan Pasal 99 KUHAP.

Namun disisi lain dalam penerapannya, Beberapa hal yang menjadi hambatan dalam melakukan perlindungan serius terkait human trafficking ini adalah sebenarnya justru dari korban itu sendiri yang terkadang melalukan pembiaran karena yang pertama tidak mampu bereaksi terhadap penyimpangan, yang kedua, sikorban atau badan kontrol lain mungkin takut akan ada akibat yang lebih serius karena pertentangan tersebut, yang ketiga, sikap tidak peduli ini sudah menjadi iklim sosial yang ditimbulkan oleh tidak adanya reaksi yang luas. ${ }^{25}$

\section{Perlindungan Anak Sebagai Pelaku Seks Komersial dalam perspektif hukum progresif}

Gagasan hukum progresif muncul karena prihatin terhadap kualitas penegakan hukum di Indonesia terutama sejak terjadinya reformasi pertengahan tahun 1997. Jika fungsi hukum dimaksudkan untuk turut serta memecahkan persoalan kemasyarakatan secara ideal, maka yang dialami di Indonesia sekarang ini adalah sangat bertolak belakang dengan cita-cita ideal tersebut.

Berkaitan dengan hal tersebut, maka hukum tidak ada untuk dirinya sendiri, melainkan untuk sesuatu yang lebih luas dan lebih besar. Tetapi pada hakekatnya teori-teori hukum yang ada berakar pada kedua faktor tersebut. Semakin landasan suatu teori bergeser ke faktor hukum, semakin suatu teori menganggap hukum sesuatu yang mutlak-otonom dan final. Semakin bergeser kemanusia, semakin teori tersebut ingin memberikan ruang kepada faktor manusia.

Penyelenggaraan Perlindungan anak berasaskan pancasila dan berasaskan Pancasila dan berdasarkan Undang-undang Dasar 1945 serta prinsip-prinisip dasar Konvensi Hak-Hak Anak yang meliputi:
a. Nondiskriminasi
b. Kepentingan terbaik bagi Anak
c. Hak untuk hidup, kelangsungan hidup dan perkembangan
d. Penghargaan terhadap pendapat anak.

\footnotetext{
${ }^{24}$ Nashrina, Perlindungan Hukum Pidana bagi Anak di Indonsia, Rajawali Pers, Jakarta, 2014, hlm. 19.

${ }^{25}$ Alfan Alfian, Upaya Perlindungan Hukum terhadap Korban Tindak Pidana Perdagangan Orang, Fiat Justisia Jurnal Ilmu Hukum Volume 9 No 3, Juli-September 2015.
} 
Hukum progresif sesungguhnya sederhana, yaitu melakukan pembebasan, baik dalam cara berfikir mauoun bertindak dalam hukum, sehingga mampu membiarkan hukum itu mengalir saja untuk menuntaskan tugasnya mengabdi kepada manusia. ${ }^{26}$

Peradilan pidana (the juvenile justice system) merupakan salah satu bentuk perlindungan yang diberikan hukum kepada anak yang telah melakukan tindak pidana. Orientasi dari keseluruhan proses peradilan pidana anak ini harus ditujukan pada kesejahteraan anak itu sendiri, dengan dilandasi prinsip kepentingan terbaik bagi anak (the best interest for children) bahwa adanya dua sasaran dibentuknya peradilan anak, yaitu:

1. Memajukan kesejahteraan anak (the promotion of the well being of the juvenile), berarti prinsip kesejahteraan anak ini harus dipandang sebagi fokus utama dalam sistem peradilan anak. Prinsip ini dapat dijadikan dasar untuk tidak menerapkan penggunaan sanksi yang semata-mata bersifat pidana, atau yang bersifat menghukum.

2. Mengedepankan prinsip proporsionalitas (theprinciple of proporsionality), merupakan sarana untuk mengekang penggunaan sanksi yang bersifat menghukum dalam arti membalas. Hal ini dipertegas Paul H. Hann mengemukakan pendapatnya bahwa pengadilan anak janganlah semata-mata sebagai suatu peradilan pidana bagi anak dan tidak pula harus berfungsi semata-mata sebagai suatu lembaga sosial. ${ }^{27}$

Jaminan umum yang dimaksud tersebut adalah jaminan-jaminan yang bersifat prosedural yang paling mendasar, antara lain:

1) Hak untuk diberitahukannya tuduhan,

2) Hak untuk tetap diam,

3) Hak untuk memperoleh penasehat hukum,

4) Hak untuk hadirnya orang tua/wali,

5) Hak untuk menghadapkan saksi danpemeriksaan silang para saksi

6) Hak untuk banding ke tingkat yang lebihtinggi.

Namun masih banyak kekurangan didalam peraturan Perundang-undangan yang secara terpisah mengatur tentang perlindungan saksi dan Korban yang seharusnya secara hukum banyak pihak yang dijadikan saksi engan untuk menjadi saksi. Hal ini karena merasa terancam jiwa dan keluarganya terhadap apa yang disampaikan, baik ditingkat penyidikan sampai di Pengadilan. Bahkan yang semulanya menjadi saksi akan tetapi akhirnya ditetapkan sebagai tersangka. ${ }^{28}$

Oleh karena itu, baik saksi korban dan pelapor dalam perkara anak mesti mendapatkan perlindungan dan bantuan hukum. Implementasi Undang Undang Perlindungan Anak (UUPA) di Indonesia dirasa masih sangat sulit diberlakukan secara sungguh-sungguh dan masih menjadi kendala. Penyebabnya tidak lain dari banyaknya yang turut menjadi konsumen atau pengguna jasa pekerja seks anak.

Selanjutnya Satjipto Raharjo mendeskripsikan bahwa lemahnya penegakan hukum pada hakikatnya merupakan penegakan ide-ide atau konsep-konsep tentang keadilan, kebenaran, kemanfaatan sosial. Penegakan hukum merupakan usaha untuk mewujudkan ide dari konsepkonsep yang menjadi kenyataan. Penegakan hukum dan penggunaan hukum adalah dua hal yang berbeda. Seseorang dapat menegakkan hukum untuk memberikan keadilan, tetapi

\footnotetext{
${ }^{26}$ Nikmah Rosidah, Budaya Hukum Hakim Anak di Indonesia, Semarang, Pustaka Magister, Semarang, 2014, hlm. 192

27 Valentina, Perdagangan perempuan dan Anak Dalam Pandangan Seorang Aktivis Perempuan; Sulistyowati Irianto (ed). Perempuan dan Hukum, Menuju Hukum yang Berperspektif Kesetaraan dan Keadilan, Yayasan Obor, Jakarta, 2008, hlm. 115.

${ }^{28}$ Laurensius Arliman Simbolon, Partisipasi Masyarakat di dalam Perlindungan Anak yang Berkelanjutan Sebagai Bentuk Kesadaran Hukum, Vol 3, No 2 (2016), Padjajaran, Jurnal Ilmu Hukum (Journal of Law)
} 
seseorang juga dapat menegakkan hukum untuk digunakan bagi pencapaian tujuan atau kepentingan lain, menegakkan hukum tidak persis sama dengan menggunakan hukum. ${ }^{29}$

Menurut Black's Law Dictionary, penegakan hukum merupakan usaha untuk menegakkan norma-norma dari kaidah-kaidah hukum sekaligus nilai-nilai yang ada di belakangnya. aparat penegak hukum hendaknya memahami benar-benar jiwa hukum (legal spirit) yang mendasari peraturan hukum yang harus ditegakkan, terkait dengan berbagai dinamika yang terjadi dalam proses pembuatan perundang-undangan (law making process). ${ }^{30}$

Menurut Hans Kelsen tujuan ilmu hukum harus terbebas dari semua ideologi politik menuju perubahan yang lebih baik untuk menjaga keseimbangan dalam masyarakat. Jika dihubungkan dengan hukum pidana maka tujuan hukum pidana adalah untuk mengetahui objektivitas dari hukum pidana positif. ${ }^{31}$

Mengingat kasus kekerasan pada anak biasanya lebih banyak terjadi pada anak dari kalangan bawah, sebagai contoh, pihak kepolisian umumnya akan malas menanganinya. Karenanya, kasus-kasus anak itu tidak bisa dijadikan lahan memperoleh uang. Sebaliknya, kalau pelaku kekerasan berasal dari golongan kaya, yang mampu membayar polisi, jaksa dan hakim, pelaku akan dibebaskan dengan mudah, dan layak. Dalam konteks Negara Indonesia, keadilan yang hendak diwujudkan sesuai dengan yang tertuang dalam sila ke 3 Pancasila. Keadilan sosial bagi seluruh rakyat Indonesia. Dengan demikian, sistem tidak hanya untuk memidana pelaku tetapi mewujudkan keadilan bagi korban kejahatan dan memanusiakan manusia yang sesuai dengan tujuan hukum progresif.

\section{J. Penutup}

Berdasarkan hasil pembahasan, maka kesimpulannya adalah sebagai berikut:

Bentuk perlindungan yang diberikan oleh Undang-undang Nomor 35 tahun 2014 tentang Perubahan atas Undang-Undang Nomor 23 tahun 2002 tentang Perlindungan Anak di atur di dalam Pasal 68 yang menyebutkan bahwa "Perlindungan khusus bagi anak korban penculikan, penjualan dan/atau perdagangan dilakukan melalui upaya pengawasan, perlindungan, pencegahan, perawatan dan rehabilitasi". Sedangkan Perlindungan terhadap anak sebagai korban perdagangan orang, berdasarkan Undang-undang. Nomor 21 Tahun 2007 tentang Pemberantasan Tindak Pidana Perdagangan Orang mengatur mengenai perlindungan saksi dan korban. Saki korban dan pelapor sudah seharusnya mendapatkan perlindungan dan bantuan hukum diamana tindak pidana dilaksanakan berdasarkan Undang-undang. Nomor 13 Tahun 2006 tentang Perlindungan Saksi dan Korban. Model perlindungan berdasarkan Undang-undang Nomor 21 Tahun 2007 tentang PTPPO tidak membedakan antara anak dengan orang dewasa.

\section{Daftar Pustaka}

A. Buku

El Majda, Muhtaj. 2008. Dimensi-dimensi HAM: Mengurai Hak Ekonomi, Sosial, dan Budaya. Jakarta: Rajawali Pers.

Hatta, Moh. 2012. Tindak Pidana Perdagangan Orang Dalam Teori Dan Praktek. Yogyakarta: Liberty Yogyakarta..

\footnotetext{
${ }^{29}$ Satjipto Rahardjo, Qodri Azizy dkk, Menggagas Hukum Progresif Indonesia, Pustaka Pelajar, Yogyakarta, 2006, hlm. 84..

${ }^{30}$ https://nasional.sindonews.com/read/761534/18/penegakan-hukum-sebagai-jalan-hidup-13739486653 Diakses pada 10 Februari 2019 pukul 21: 07 WIB.

${ }^{31}$ Eddy O.S Hiariej, Prinsip-Prinsip Hukum Pidana Edisi Revisi, Yogyakarta: Cahaya Atma Pustaka, hlm. 13.
} 
Iksan, Muchamad. Hukum Perlindungan Saksi dalam Sistem Peradilan Pidana Indonesia, Surakarta: Muhammadiyah University Press.

Irwanto. 2001. Perdagangan Anak di Indonesia, Suatu diskripsi Awal, Jakarta: Kantor Peburuhan Internasional

Maidin, Gultom. 2013. Perlindungan Hukum Terhadap Anak Dan Perempuan. Bandung: Refika Aditama.

Muladi dan Arif, Barda Nawai. 2010. Teori-Teori dan Kebijakan Pidana. Bandung: Alumni. Nashrina. 2014. Perlindungan Hukum Pidana bagi Anak di Indonsia. Jakarta: Rajawali Pers. Rahardjo, Satjipto dkk, Menggagas Hukum Progresif Indonesia, , Yogyakarta: Pustaka Pelajar. Rosidah, Nikmah. 2014. Budaya Hukum Hakim Anak di Indonesia. Semarang: Pustaka Magister. Valentina. 2008. Perdagangan perempuan dan Anak Dalam Pandangan Seorang Aktivis Perempuan; Sulistyowati Irianto (ed). Perempuan dan Hukum, Menuju Hukum yang Berperspektif Kesetaraan dan Keadilan. Jakarta: Yayasan Obor.

B. Jurnal

Ardianto, "Perlindungan Hukum Terhadap Anak Sebagai Korban Dari Tindak Pidana Perdagangan Orang Di Kota Pekanbaru." Jurnal Ilmu Hukum, Vol. 4; No. 1, (accessed July 16, 2020): 131, https://jih.ejournal.unri.ac.id/index.php/JIH/article/view/1041/1034.

Alfian, Alfan. "Upaya Perlindungan Hukum Terhadap Korban Tindak Pidana Perdagangan Orang Legal Protection Against Crime Victims of Human Trading." Fiat Justisia Jurnal Ilmu Hukum Vol. 9, No. 3, 2015: 331-339 https://jurnal.fh.unila.ac.id/index.php/fiat/article/view/603.

Dalimoenthe, Ikhlasiah. "Jurnal Pendidikan Ilmu-Ilmu Sosial Pemetaan Jaringan Sosial Dan Motif Korban Human Trafficking Pada Perempuan Pekerja Seks Komersial." JUPIIS: JURNAL PENDIDIKAN ILMU-ILMU SOSIAL. vol. 10, No. 1, June 29, 2018: 91103,https://doi.org/10.24114/JUPIIS.V10I1.8430.G9061.

El Majda, Muhtaj. 2008. Dimensi-dimensi HAM: Mengurai Hak Ekonomi, Sosial, dan Budaya. Jakarta: Rajawali Pers Herlyanty,Yuliana Angraeny Bawole. "Implementasi Hukum Hak Asasi Manusia Dalam Pengaturan Pencegahan Tindak Pidana Perdagangan Orang Di Indonesia." LEX CRIMEN. vol. II, August 16, 2013: 97-111 https://ejournal.unsrat.ac.id/index.php/lexcrimen/article/view/2429.

Hatta, Moh. 2012. Tindak Pidana Perdagangan Orang Dalam Teori Dan Praktek. Yogyakarta: Liberty Yogyakarta..

Hasyim Azizurrahman, " Pembaharuan Kebijakan Pidana Kejahatan Perdagangan Orang (Studi Di Wilayah Perbatasan Kalimantan Barat-Sarawak)." Yustisia Jurnal Hukum, Vol. 3, No. 2 $\begin{array}{llll}\text { accessed July 88-99, } & \text { 2020: }\end{array}$ https://jurnal.uns.ac.id/yustisia/article/view/11100/9932.https://endangshastuti.wordpress.co m/perdagangan-manusia/

Iksan, Muchamad. Hukum Perlindungan Saksi dalam Sistem Peradilan Pidana Indonesia, Surakarta: Muhammadiyah University Press.

Irwanto. 2001. Perdagangan Anak di Indonesia, Suatu diskripsi Awal, , Jakarta: Kantor Peburuhan Internasional

Jamilah, Asiyah, and Nyoman Serikat Putra Jaya. "Justitia Jurnal Hukum Fakultas Hukum Universitas Muhammadiyah Surabaya 2." JUSTITIA JURNAL HUKUM 4, Vol.4, no. 1, April 15, 2020: 1-18,. https://m.liputan6.com/regional/read.

Kusuma, Ayu Amalia. "Efektivitas Undang-Undang Perlindungan Anak Dalam Hubungan Dengan Perlindungan Hukum Terhadap Anak Korban Perdagangan Orang Di Indonesia." LEX ET SOCIETATIS. vol. 3, February 13, 2015: 64-71. http://news.okezone.com/read/2014/.

Nuraeny, Henny. "Penyuluhan Hukum Mengenai Undang-Undang Nomor 21 Tahun 2007 Tentang Pemberantasan Tindak Pidana Perdagangan Orang Bagi Guru Bimbingan Konseling Dan Siswa/Siswi Smk/Sma/Ma Se-Kabupaten Cianjur." JOURNAL OF EMPOWERMENT. vol. 1, No. 1, July 1, 2017: 25-38. https://jurnal.unsur.ac.id/index.php/JE.

Okky RI Chahyo Nugroho, "Tanggung Jawab Negara Dalam Penanganan Tindak Pidana Perdagangan Orang (State's Responsibility in Mitigation of Human Trafficking Crime)," Jurnal Penelitian Hukum De Jure 18, Vol. 18, No. 4, December 10, 2018: 16-27, 
https://doi.org/10.30641/dejure.2018.V18.543-560.

Putri, Eka Intan. "Begal Anak; Pemenuhan Hak Dan Lembaga Pembinaan Khusus Anak Kelas II A Bandar

Qudus, Muh Abdul. "Pertanggungjawaban Korporasi Terhadap Tindak Pidana Human Trafficking Di Indonesia.” Jurnal Komunikasi Hukum (JKH) 5, no. 2, November 17, 2019: 26-39. https://ejournal.undiksha.ac.id/index.php/jkh/article/view/18237.

Rahardjo, Satjipto dkk, Menggagas Hukum Progresif Indonesia, , Yogyakarta: Pustaka Pelajar.

Rosidah, Nikmah. 2014. Budaya Hukum Hakim Anak di Indonesia. Semarang: Pustaka Magister.

Simbolon, Laurensius Arliman. "Partisipasi Masyarakat Di Dalam Perlindungan Anak Yang Berkelanjutan Sebagai Bentuk Kesadaran Hukum." PADJADJARAN Jurnal Ilmu Hukum (Journal of Law) 3, no. 2, October 20, 2016: 310-29. https://doi.org/10.22304/pjih.v3n2.a5.

Sitania, "Akomodasi Pemberantasan Tindak Pidana Perdagangan Orang Dalam Aspek Hukum Internasional Dan Nasional." Jurnal Pembangunan Hukum Indonesia." Vol. 2 No. 1, accessed July 16, 2020: 38-53. https://ejournal2.undip.ac.id/index.php/jphi/article/view/7209/3695.

Sulistiyo, Agung. "Perlindungan Korban Kekerasan Kejahatan Perdagangan Manusia Dalam Sistem Hukum Pidana Indonesia." Pandecta : Jurnal Penelitian Ilmu Hukum (Research Law Journal). Vol. 7, 2012. http://journal.unnes.ac.id/nju/index.php/pandecta.

Valentina. 2008. Perdagangan perempuan dan Anak Dalam Pandangan Seorang Aktivis Perempuan; Sulistyowati Irianto (ed). Perempuan dan Hukum, Menuju Hukum yang Berperspektif Kesetaraan dan Keadilan. Jakarta: Yayasan Obor.

Widiastuti, Tri Wahyu. "Upaya Pencegahan Tindak Pidana Perdagangan Orang (Trafficking)."

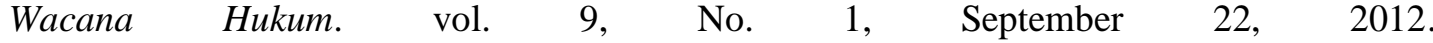
http://www.ejurnal.unisri.ac.id/index.php/Wacana/article/view/308.

C. Undang-Undang

Undang-Undang Nomor 35 Tahun 2014 tentang Perlindungan Anak.

Undang-Undang Nomor 12 Tahun 2007 tentang Pemberantasan Tindak Pidana Perdagangan Orang.

Undang-Undang Dasar 1945.

K. Internet

http://jakarta.tribunnews.com/2019/01/12/prostitusi-pelajar-di-lampung-terbongkar-ibu-anakjadimuncikari-beginimodusnya?page=all\#gref.

https://nasional.sindonews.com/read/761534/18/penegakan-hukum-sebagai-jalan-hidup1373948653 